\title{
Utilization of Crushed Ceramic Tile Wastes as Partial Replacement of Coarse Aggregate in Concrete Production
}

\author{
Bikash Subedi \\ Department of Civil and Geomatics Engineering, \\ Pashchimanchal Campus, Institute of Engineering, \\ Tribhuvan University, Nepal
}

\author{
Dhurba Kumar Wagle \\ Department of Civil and Geomatics Engineering, \\ Pashchimanchal Campus, Institute of Engineering, \\ Tribhuvan University, Nepal;
}

\author{
Keshav Basnet \\ Department of Civil and Geomatics Engineering, \\ Pashchimanchal Campus, Institute of Engineering, \\ Tribhuvan University, Nepal;
}

\begin{abstract}
A large bulk of broken ceramic tiles change into wastage, these waste materials are not reusable and recyclable due to their physical and chemical structure. Reuse of waste tiles in construction sector helps to reduce the over quarrying of aggregate and also helps in proper management of waste in urban area. This experimental study deals with the investigation of possibility of using waste ceramic tile in concrete. In this study the physical characteristics of ceramic tile aggregate are measured. They are used in concrete as the substitute for coarse aggregates with $0,5,10,15,20,25,30$ and 35 percentage of substitution. All other materials (cement, sand, coarse aggregate) of same properties are used for each samples. This experimental study found that the waste ceramic tile aggregate has permissible flakiness index, elongation index, fineness modulus, impact value. Specific gravity and water absorption value of tile aggregate are also obtained. Compressive and split tensile strength observed are good in most of the composition. This study finds that the use of waste ceramics tile could be the better solution for ceramics waste management. Also for increase in concrete quality 15 to 25 percentage addition of ceramic tile aggregate could have done.
\end{abstract}

Keywords-Aggregate, Ceramic Tile, Concrete, Recycling, Solid Waste

\section{INTRODUCTION}

\section{A. Background}

Concrete is one of the key construction materials worldwide. Large amount of concrete is being used in construction industry. Use of concrete implies use of cement, fines and coarse aggregate as well. Aggregate is key ingredient in terms of strength and volume in concrete. Aggregate is non-renewable natural resource. The resources in our country are being overexploited and the natural stock is decreasing at an alarming rate. Use of waste tile aggregate as replacement for coarse aggregate helps to reduce overexploitation as well as manage the waste.

The amount of tile waste on earth is enough for use as an aggregate in concrete. Tile is produced from natural materials sintered at high temperatures. There are no harmful chemicals in tile. Waste tiles cause only the apparition of pollution. However, some parts of tiles are used in cotto as flooring and also flooring in tennis courts, walkways, cycling paths and gardens as a ground material. Therefore, waste tiles are stored in factory fields because of their economic value. These waste materials can be recycled to save money. Crushed tile aggregate is a material especially proposed for the buildings constructed in hot climates. The unit weight of concrete is decreased with use of the CTA compared to the control concrete [1].

Rapid industrial development causes serious problems all over the world such as depletion of natural aggregates and creates enormous amount of waste material from construction and demolition activities. One of the ways to reduce this problem is to utilize the waste. A large quantity of wastages produced annually in all countries, in particular construction and demolition waste contribute the highest percentage of wastes worldwide about $75 \%$. Furthermore, ceramic materials contribute the highest percentage of wastes within the construction and demolition wastes about $54 \%$ [2]

Ceramic waste can be transformed into useful coarse aggregate. The properties of ceramic waste coarse aggregate are well within the range of the values of concrete making aggregates. The properties of ceramic waste coarse aggregate concrete are not significantly different from those of conventional concrete. The use of ceramic waste coarse aggregate concrete has increased because it has various advantages over other cementations materials [3]. It has been estimated that about $30 \%$ of the daily production in the ceramic industry goes to waste. This waste is not recycled in any form at present. However, the ceramic waste is durable, hard and highly resistant to biological, chemical and physical degradation forces. As the ceramic waste is piling up every day, there is pressure on the ceramic industries to find a solution for its disposal. Meanwhile, conventional crushed stone aggregate reserves are depleting fast, particularly in some desert regions of the world. Use of inorganic industrial residual products in making concrete will lead to sustainable concrete design and greener environment (Senthamarai and Manoharan, 2005). Recycling and reusing aggregate from demolished building is not a new concept several countries have been 
used crushing waste aggregate for a number of years. However, the produced aggregate has been mainly limited to such a low level by using it as pipe bedding, site fill, sub base, or as a capping layer [4]. So, recycled waste ceramic tile from building also can be used as various forms of aggregate.

\section{B. Study Area}

Pokhara city known as biggest city of the Nepal with its unique scenery attracts local and international tourist. People are migrating from its vicinity for the Settlement and other opportunities that resulting rate of construction of infrastructure at high rate day by day. There are 4,462,957 houses in Nepal and 84,246 on kaski district. 60.7\% houses on kaski district are made up of cement and RCC (cement building 33.5\% and RCC building 27.2\%) [4]. Almost all building uses ceramic tiles and the wastes tiles produced during the construction of these buildings produce a critical problem on waste management.

In this research work, the waste ceramics tile was collected from nearby supplier (Bijen Supplier, Savagriha chowk). Cement for the concrete production is collected from nearby supplier. Aggregate used for testing is collected from nearby suppliers from Pokhara.

\section{Statement of Problem}

Modern world nowadays has a large problem with solid waste. It is evident in the construction industry that debris from wastage coming from all sorts of engineering materials is a major problem that we need to address. These wastes bring about environment issues that lead to the economic growth of country. The research aims to provide a solution to problems on waste generation cause by ceramic tiles production and usage in construction. Nepal is developing and rapidly urbanizing country. With more people migrating towards city there is increased work on construction industry. Ceramic tile is used as construction material in almost all construction industry. Each year approximately 250,000 tons of tiles are worn out over the world, while 100 million tiles are used for repairs [1]. These waste materials can be recycled to save money and environment. Also being limited source of construction material in the world, it needs to be searched as substitute material to maintain the depletion construction rate. Natural coarse aggregates are generally extracted from larger rock formations through a process of open excavation. The aggregate, quarrying process causes a negative effect to environment.

As a developing country, Nepal also has been affected by this construction waste problem in the same situation with the rapid development of the construction sector. The statistics of construction waste that's been produced have shown estimated that almost $10 \%$ to $30 \%$ percent originates from construction and demolition activities as globally "unpublished" [5].

\section{Objectives of the Study}

The main objective of this study is to conclude the feasibility of use of ceramic tile waste as the main aggregate by partial replacement of coarse aggregate. Ceramic waste could be transformed into useful coarse aggregate. The aim of this study was to produce and test
M20 quality concrete with ceramic tile waste. The compressive and flexural strength results of the concretes will be determined by curing 7 and 28 days. The aim of this study is the assessment of the properties of concrete which use ceramic tile waste as natural coarse aggregate partial substitute. To achieve this, hardened state properties of concrete are measured to ensure that fundamental parameters needed in design are evaluated.

Also the following objectives was performed,

1. Comparison of compressive and split tensile strength of concrete by destructive and nondestructive test (i.e. cube test and rebound hammer test respectively).

2. Economic feasibility study of using waste ceramic tile aggregate as partial replacement of coarse aggregate in concrete production.

3. Comparison between combined flakiness and elongation index, mechanical properties (Aggregate crushing value, Aggregate impact value, Aggregate abrasion value) of waste ceramic tile aggregate (CTA) and natural coarse aggregate (NCA).

4. Comparison between specific gravity and water absorption value of different proportion of waste ceramic tile aggregate mix.

\section{E. Scope}

Ceramic tile industry produces large amount of waste during mining and processing stages. Ceramic tiles are also wasted during construction stage of new building. This waste is dumped on open land which creates lot of environmental as well as health problems. Therefore, it is necessary to utilize this waste material as a construction material in concrete production. Ceramic wastes have special properties, which can contribute positively in other areas of recycling.

The study identifies physical properties of CTA as a partial or full replacement for natural coarse aggregate. Also, this study will help designers and planners to seek CTA as a good alternative to natural coarse aggregate. So, they can manage the ceramic tile waste by product. Aggregate occupies between $70 \%$ and $80 \%$ of the total concrete volume, and because of that the strength of aggregate is very important for the final strength of the concrete [6]. Thus the study on concrete aggregates is the important issues for the area of civil engineering.

Thus, the use of tile wastes has two main benefits for society, one is it helps on improving the quality of concrete and another is it helps on maintaining the environment.

\section{F. Limitations}

Some limitations of this study are listed below,

1. Chemical test was not performed for any of the concrete materials (i.e. cement, sand, aggregate and water).

2. There are many brand of cement available within local market but this study considers the single brand Ordinary Portland Cement named as Shivam cement.

3. Tap water (i.e. potable water) was used for concrete mix as well as curing (i.e. no consideration of $\mathrm{pH}$ value). 
4. Water temperature was not maintained (i.e. $27 \pm 2$

\section{LITERATURE REVIEW}

\section{A. Ceramic Tile}

Ceramic tiles are important construction materials used in almost all buildings. The term ceramics is a general term used to refer to ceramic products. Common manufactured ceramics include wall tiles, floor tiles, sanitary ware, household ceramics and technical ceramics. In essence, ceramic is a term used to describe inorganic materials (with possibly some organic content), made up of non-metallic compounds and made permanent by a firing process (Reference Document by Best Available Techniques (BAT) in the Ceramic Manufacturing Industry, 2007).The global production of ceramic tile in the world is about 8500 million square meters [7]. The basic raw material for ceramics tile is clay, which derives from a granite type rock, having decomposed over millions of years. Studies shows that large amount of ceramic tiles were broken and wasted during production, transportation and during construction.

\section{B. Ceramic Tile Wastes as Aggregate}

Ceramic tile waste is durable, hard and highly resistant to Biological, Chemical and Physical degradation forces. Ceramic tile aggregate are hard having considered value of specific gravity, rough surface on one side and smooth on other side, are lighter in weight than normal stone aggregates. Ceramic wastes can be separated in two categories in accordance with the source of raw materials. The first one are all fired wastes generated by the structural ceramic factories that use only red pastes to manufacture their products, such as brick, blocks and roof tiles. The second one is all fired waste produced in stoneware ceramic such as wall, floor tiles and sanitary ware. These producers use red and white pastes, nevertheless, the usage of white paste is more frequent and much higher in volume [8]. The ceramics industry is comprised of the following subsectors: wall and floor tiles, sanitary ware, bricks and roof tiles, refractory materials, technical ceramics and ceramic materials for domestic and ornamental use [9].

On the study of Ceramic tile waste used in concrete as a replacement for natural coarse aggregate with $0 \%, 10 \%$, $20 \%$ and $30 \%$ of the substitution and M20 grade concrete. The concrete moulds were casted and tested for Compressive Strength and Split Tensile Strength after a curing period of 3, 7 and 28 days. The results indicate that, the maximum compressive strength is obtained for the $30 \%$ replacement of ceramic tile aggregate with natural coarse aggregate [10].

Ceramic waste can be transformed into useful coarse aggregate. The properties of ceramic waste coarse aggregate are well within the range of the values of concrete making aggregates. The properties of ceramic waste coarse aggregate concrete are not significantly different from those of conventional concrete. The use of ceramic waste coarse aggregate concrete has increased because it has various advantages over other cementitious materials [3]. degree centigrade) during curing.

Ceramic wastes are produced as a result of the ceramic processing. These wastes cause soil, air and groundwater pollution. The pollutant of ceramic industry which are mud and tile are coming from the ceramic plant's refinery systems are stored in the waste disposal site of the plant.

The reuse of solid wastes and aggregates from construction and demolition waste is showing a prospective application in construction and as alternative to primary and natural aggregates. It conserves natural resources and reduces the space required for land fill disposal. There is no doubt that the use of industrial wastes as cost-free raw materials will represent substantial savings for civil construction. In the study researcher did not include an economic feasibility study. So the cost comparison is also necessary topic of research nowadays.

Sustainable development is a key towards improving living conditions of the future generations. Thus recycling wastes is only rational and logical step towards conservation of natural resources. The economic aspect of recycling is motivation to proceed in this direction. So the use of recycled tile aggregate steps forward to new economic, pollution less, environment friendly society. For the healthy environment of city reuse of waste tile as aggregate is a positive works for the world.

The tile produced in different location and climate may have different physical and mechanical properties. These properties may create noticeable difference on the quality of concrete produced from these tiles. Also the different ratio of natural and waste tile aggregate will cause significance difference in results. Not only tiles properties but also the natural aggregates properties may cause different results on concrete quality. Different location and climate have different types of natural aggregate so this study have to carried out on different country for the reliability of the quality of concrete.

\section{Cement}

Cement is a fine powder, which when mixed with water and allowed to set and harden, is capable of uniting fragments or masses of solid matter together to produce a mechanically strong material. The most commonly used cement is Ordinary Portland cement of 53 grade.

\section{Fine and Coarse Aggregate}

Fine aggregates generally consist of natural sand or crushed stone with particles passing through a $4.75 \mathrm{~mm}$ (No. 4) sieve. The fractions ranges from $4.75 \mathrm{~mm}$ to 150 microns are termed as fine aggregate. The sand particles should also pack to give minimum void ratio, higher voids content leads to requirement of more mixing water.

Those particles that are predominantly retained on the $4.75 \mathrm{~mm}$ (No. 4) sieve and was pass through 3-inch screen are called coarse aggregate. The coarser the aggregate, the more economical will be the mix. Larger pieces offer less surface area of the particles than an equivalent volume of small pieces. Use of the largest permissible maximum size of coarse aggregate permits a reduction in cement and water requirements. 


\section{RESEARCH METHODOLOGY}

\section{A. Collection of Materials}

Coarse aggregate and fine aggregate required for this experimental research work are collected from Kotre crusher, Tanahu, Nepal. Shivam OPC cement is used for test. Floor and wall tiles from tile suppliers are collected and then it was crushed by manual hammering method to make it coarse aggregate.

\section{B. Material Properties and Specimen Preparation} Cement

Cement used for the tests is Shivam OPC cement. The tests on cement were carried out based on IS: 4031-1998. The tests performed are as follows

\section{Fineness test:}

The fineness of cement is calculated by sieve analysis method (dry sieving method). Fineness is checked for the quality of the cement material. Fineness of cement is responsible for the hydration and hence rate of gain of strength and also the rate of evolution of heat. If the cement is fine than grater is its cohesiveness, which is the property required in the concrete because it gives compaction to the concrete.

Fineness of cement is determined by following guidelines outlined in IS: 4031 Part III.

\section{Setting time:}

Initial and final setting time of cement was determined following the guidelines outlined in IS: 4031 Part V. In our cement sample we found $55 \mathrm{~min}$ for initial setting time and $325 \mathrm{~min}$ for final setting time. This is in between $30 \mathrm{~min}$ and 600 minutes.

Sand

The sand used for the work is natural uncrushed sand and Sand was obtained from the suppliers located in Kotre Tanahu. The tests performed are listed as,

\section{Gradation:}

Sieve Analysis of sand was done to find the grading zones. The sieve sizes used were $10 \mathrm{~mm}, 4.75 \mathrm{~mm}, 2.36$ $\mathrm{mm}, 1.18 \mathrm{~mm}, 600$ microns, 300 microns, 150 microns. The tests were performed in accordance to IS: 2386 Part I. Grading was done based on table 4 of IS: 383-1970.

\section{Fineness modulus:}

The Fineness modulus (FM) is an empirical figure obtained by adding the total percentage of the sample of an aggregate retained on each of a specified series of sieves, and dividing the sum by 100 .

Water Absorption and Specific Gravity:

To determine the water absorption and specific gravity of fines i.e. sand, use of pycnometer was done and the procedures involved was in accordance to IS:2386 Part III Cl. 2.4.

\section{Coarse Aggregate}

Coarse aggregates used for the study were Natural Aggregates and grinded ceramic tile aggregate. The sample of ceramic tiles are collected from Bijen suppliers, Savagriha chowk, Pokhara, then it was grinded by manual hammering and sieved as per IS sieve. Few tests (specific gravity, water absorption, water content, impact value) on Tile samples were done on Pashchimanchal Campus lab.
Natural aggregates were crusher run aggregate obtained from Crusher located in Pokhara. To determine the physical properties of aggregate following tests were performed.

Sieve Analysis:

Sieve Analysis of aggregate was done to find the grading zones. The sieve sizes used were $25 \mathrm{~mm}, 20 \mathrm{~mm}$, $16 \mathrm{~mm}, 12.5 \mathrm{~mm}, 10 \mathrm{~mm}, 4.75 \mathrm{~mm}$ and pan. The tests were performed in accordance to IS: 2386 Part I.

Water Absorption and Specific Gravity:

Water absorption and specific gravity of aggregates are needed to be determined. The designs i.e. mix designs are based on specific gravity and water absorption. The tests were performed in accordance to IS: 2386 Part III.

\section{Flakiness and elongation index.}

Flaky or elongated materials, when used in the construction of a pavement, may cause the pavement to fail due to the preferred orientation that the aggregates take under repeated loading and vibration. It is important that the flakiness and elongation of the aggregate are contained to within permissible levels.

Aggregate Impact Value:

This test gives relative measure of resistance of an aggregate to impact load. The test performed was based on IS: 2386 Part V Clause 4.

The results of physical tests were used in the design process. The obtained mix design ratios are tabulated. Preparation of Specimen and Concrete Mix Design

Concrete of M25 was used for the study. Mixed design of concrete based on Indian standard was done for the testing purpose. IS10262:2009, IS 456:2000 and SP 23 were used during the design of concrete mix. The results of physical tests were used in the design process.

\section{Tests on Hardened Concrete}

Tests performed on concrete during the study are as Cube Test:

This test is performed to measure the compressive strength of the concrete. Cubes of $150 \mathrm{~mm}$ size were used for the purpose of test. Cubes were tested for compressive strength at 7 and 28 days. IS: 516 Clause 5 was followed in the test. The procedures followed can be listed as

1. The specimen was removed from water 24 hours prior to test and let dry in air and weight of the specimen was measured.

2. The bearing surface was wiped off and cleaned off the loose particles which are in contact with compression plates.

3. The cube was placed in the machine aligning properly with the center of circular plate.

4. Static application of load was done uniformly at the rate of $140 \mathrm{~kg} / \mathrm{sq}$. cm/min until the resistance of the specimen to the increasing load breaks down and no greater load can be sustained.

5. The maximum load sustained was recorded.

6. The compressive strength was calculated as the ratio of maximum sustained load to area of load applied.

Density of Concrete:

This test is performed to measure the density of the concrete. Cubes of $150 \mathrm{~mm}$ size were used for the purpose 
of test. Densities of cubes were measured at 7, 28 days.

The steps followed while performing tests are as:

$$
\text { Density of concrete }=\frac{\mathrm{w}}{\mathrm{V}} \quad \text { Equation } 1
$$

Splitting Tensile Test:

Cylindrical specimen of $10 \mathrm{~cm}$ diameter and $20 \mathrm{~cm}$ height were used for the splitting tensile test. The tests were performed in 7 and 28 days cured sample. The steps followed while performing tests are as:

1. The specimen was taken out of water 24 hours prior to test.

2. The specimen was wiped clean and dry.

3. Two diametrical lines were drawn on the two ends of the cylinder to ensure that they align in the same axis.

4. The weight and dimension of the specimen was measured.

5. The specimen was aligned such that the lines on the ends are vertical and centered over the bottom plate.

6. Ply strip was placed above the specimen.

7. The upper plate was made touch ply strip.

8. Load was applied uniformly statically at the rate of $14-21 \mathrm{~kg} / \mathrm{cm}^{2} / \mathrm{min}$.

9. The breaking load $\mathrm{P}$ was measured.

Splitting Tensile Strength $=\frac{2 \mathrm{P}}{\pi \mathrm{DL}} \quad$ Equation 2

C. Data Analysis

To meet the objectives of the study, test results were analyzed and interpreted using statistical tools. statistical tools which is used in this research are described in brief below.

\section{Regression Analysis}

Regression analysis is use to establish the relationship between sets of variables. It was use to find the curve of best fit along with the equation. A method of least squares is the most commonly used technique in regression analysis. After the establishment of relationship, interpolation can be done. The relation obtained are linear, exponential, and polynomial and so on.

\section{Research Framework}

M25 grade concrete cube were made for the test. After curing 7 and 28 days, lab tests have done on each sample. The experimental research work has completed according to the following flow chart.

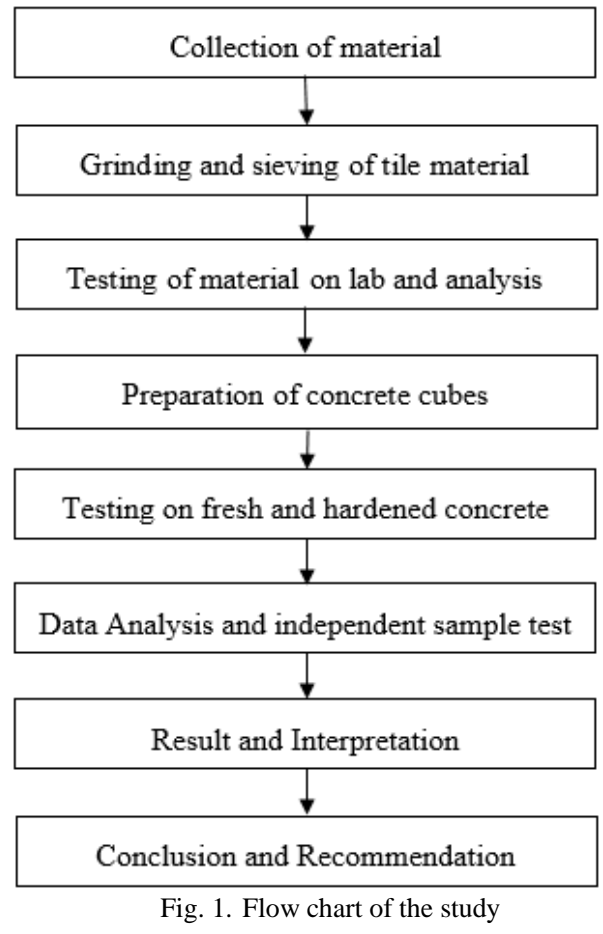

RESULTS AND DISCUSSIONS

The main findings of this research works are summarize below.

\section{A. Material and their Properties}

Cement, sand, aggregate, ceramic tile aggregate and water are the main material used in this research work. Some tests on material except water are done on civil engineering laboratory of Pashchimanchal Campus. The properties of these materials are discussed below.

Cement

Cement used for the tests is Shivam OPC Cement. Cement was used within one month of manufacturing date. The tests on cement were carried out based on IS: 40311998. The tests performed are as follows,

\section{Fineness test:}

Fineness test of cement was determined following steps outlined in IS: 4031 Part I. The fineness value obtained is 3.85 .

\section{TABLE I. FINENESS TEST OF CEMENT}

\begin{tabular}{|c|c|c|c|c|}
\hline SN & $\begin{array}{c}\text { total wt. of } \\
\text { sample } \\
\text { taken (gm) }\end{array}$ & $\begin{array}{c}\text { sample } \\
\text { retained on } \\
\mathbf{9 0 \mu} \text { sieve }\end{array}$ & fineness \% & $\begin{array}{c}\text { average } \\
\text { Fineness \% }\end{array}$ \\
\cline { 1 - 3 } 1 & 100 & 3.4 & 3.4 & \multirow{2}{*}{3.85} \\
\hline 2 & 100 & 4.3 & 4.3 & \\
\hline
\end{tabular}

\section{Setting time:}

The cement sample was found 55 min for initial setting time and $325 \mathrm{~min}$ for final setting time. This is in between 30 min and 600 minutes.

Sand

Sand used for the tests was obtained from the suppliers located in Kotre. The tests performed are listed as, 


\section{Gradation:}

Sieve Analysis of sand was done to find the grading zones. The sieve sizes used were $10 \mathrm{~mm}, 4.75 \mathrm{~mm}, 2.36$ $\mathrm{mm}, 1.18 \mathrm{~mm}, 600$ microns, 300 microns, 150 microns.
The tests were performed in accordance to IS: 2386 Part I. Grading was done based on table 4 of IS: 383-1970.

\begin{tabular}{|c|c|c|c|c|c|c|c|}
\hline \multirow{3}{*}{ IS sieve size } & \multirow{2}{*}{\multicolumn{3}{|c|}{ wt. of aggregate retained (gm) }} & \multirow{3}{*}{$\begin{array}{c}\% \text { of total } \\
\text { weight retained }\end{array}$} & \multirow{3}{*}{$\begin{array}{l}\text { cumulative } \% \text { of } \\
\text { total weight } \\
\text { retained }\end{array}$} & \multirow{3}{*}{$\%$ passing } & \multirow{3}{*}{$\begin{array}{l}\text { Permissible value } \\
\text { as per IS } 383\end{array}$} \\
\hline & & & & & & & \\
\hline & $\mathbf{i}$ & ii & iii & & & & \\
\hline $10 \mathrm{~mm}$ & 0 & 0 & 0 & 0.00 & 0.00 & 100.00 & 100 \\
\hline $4.75 \mathrm{~mm}$ & 48 & 57 & 45 & 5.00 & 5.00 & 95.00 & $95-100$ \\
\hline $2.36 \mathrm{~mm}$ & 91 & 93 & 88 & 9.07 & 14.07 & 85.93 & $75-100$ \\
\hline $1.18 \mathrm{~mm}$ & 144 & 170 & 220 & 17.80 & 31.87 & 68.13 & $55-90$ \\
\hline $600 \mu \mathrm{m}$ & 262 & 293 & 196 & 25.03 & 56.90 & 43.10 & $35-59$ \\
\hline $300 \mu \mathrm{m}$ & 239 & 244 & 302 & 26.17 & 83.07 & 16.93 & $8-30$ \\
\hline $150 \mu \mathrm{m}$ & 216 & 143 & 149 & 16.93 & 100.00 & 0.00 & $0-10$ \\
\hline total & 1000 & 1000 & 1000 & & 290.90 & 409.10 & 0 \\
\hline
\end{tabular}

Fineness modulus:

The Fineness modulus (FM) is an empirical figure obtained by adding the total percentage of the sample of an aggregate retained on each of a specified series of sieves, and dividing the sum by 100 . The fineness modulus of sand used is 2.91 .

Water Absorption and Specific Gravity:

To determine the water absorption and specific gravity of fines i.e. sand, use of pycnometer was done and the procedures involved was in accordance to IS:2386 Part III Cl. 2.4.

Coarse Aggregate

Some of the tests was done on coarse aggregates are discussed below.

Flakiness and Elongation Index:

Flakiness and elongation index for two sets of aggregate was done. First set is natural crushed aggregate and second is crushed tile aggregate. Flakiness and elongation index obtained are shown in table below. Flakiness and elongation index of CTA falls within a permissible range, while crushed natural aggregate does not.

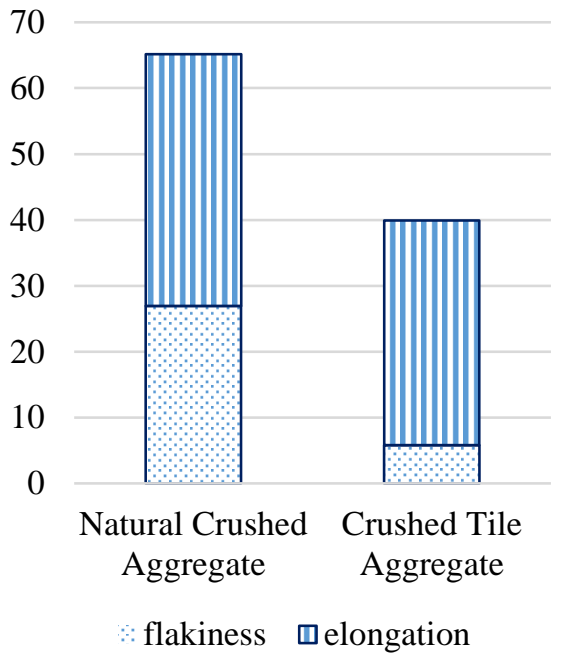

Fig. 2. Flakiness and elongation index of aggregates

TABLE III. FLAKINESS AND ELONGATION DATA OF CRUSHED AGGREGATE

\begin{tabular}{|c|c|c|c|c|}
\hline Sieve size range (mm) & Weight $\mathbf{( g m})$ & Flaky aggregate (gm) & Remaining weight (gm) & Elongated aggregate weight(gm) \\
\hline $25-20$ & - & - & - & - \\
\hline $20-16$ & 1487 & 513 & 974 & 328 \\
\hline $16-12.5$ & 1008 & 222 & 786 & 394 \\
\hline $12.5-10$ & 485 & 112 & 373 & 166 \\
\hline $10-6.3$ & 265 & 27 & 238 & 19 \\
\hline total wt. & 3245 & 874 & 2371 & 907 \\
\hline
\end{tabular}

TABLE IV. FLAKINESS AND ELONGATION DATA OF CRUSHED TILE AGGREGATE

\begin{tabular}{|c|c|c|c|c|}
\hline Sieve size range (mm) & Weight(gm) & Flaky aggregate (gm) & Remaining weight (gm) & $\begin{array}{c}\text { Elongated aggregate } \\
\text { weight(gm) }\end{array}$ \\
\hline $25-20$ & 0 & 0 & 0 & 0 \\
\hline $20-16$ & 1338 & 0 & 1338 & 310 \\
\hline $16-12.5$ & 350 & 95 & 255 & 130 \\
\hline $12.5-10$ & 230 & 9.5 & 220.5 & 160 \\
\hline $10-6.3$ & 82 & 11.3 & 70.7 & 43.5 \\
\hline total wt. & 2000 & 115.8 & 1884.2 & 643.5 \\
\hline
\end{tabular}


Flakiness index of natural crushed aggregate from Kotre crusher was obtained as $26.93 \%$ and Elongation index was $38.25 \%$.

Flakiness index of CTA was obtained as $5.79 \%$ and Elongation index was $34.15 \%$. This was better than natural crushed aggregate. So manually crushed tile aggregate have better flakiness and elongation behavior than that of natural aggregate.

Aggregate Impact Value:

The aggregate impact value obtained for natural crushed and crushed tile aggregates are presented on table below. Impact value of both NA and CTA falls within a permissible range. CTA shows better impact performance than NA. Tile chips has better impact resisting capacity.

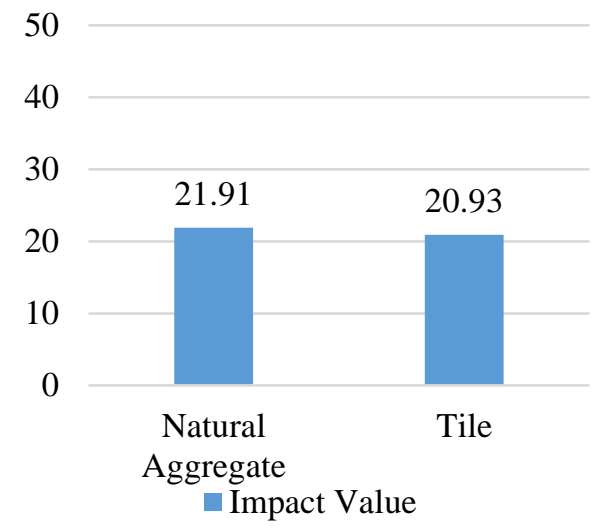

Fig. 3. Impact value of natural and tile aggregate

TABLE V. IMPACT VALUE OF AGGREGATE

\begin{tabular}{|c|c|c|c|c|c|c|}
\hline Sample & Set & Wt. of aggregate, (W1) & $\begin{array}{c}\text { Wt. of } \\
\text { aggregate } \\
\text { passed through } \\
2.36 \mathrm{~mm} \text { sieve, }\end{array}$ & Impact Value & average Impact Value & Remarks \\
\hline \multirow{2}{*}{ Natural Aggregate } & i & 317.1 & 65.7 & 20.72 & \multirow{2}{*}{21.91} & \multirow{2}{*}{$<45 \%$} \\
\hline & ii & 329.5 & 76.1 & 23.10 & & \\
\hline \multirow{2}{*}{ Tile } & $\mathrm{i}$ & 233.1 & 49.3 & 21.15 & \multirow{2}{*}{20.93} & \multirow{2}{*}{$<45 \%$} \\
\hline & ii & 228.4 & 47.3 & 20.71 & & \\
\hline
\end{tabular}

\section{Size and Grading:}

The calculated values of fineness modulus of different proportion of mixes are presented on table below.

TABLE VI. FINENESS MODULUS OF COARSE AGGREGATE

\begin{tabular}{|c|c|}
\hline CTA \% & Fineness Modulus \\
\hline 0 & 3.5 \\
\hline 5 & 3.55 \\
\hline 10 & 3.41 \\
\hline 15 & 3.58 \\
\hline 20 & 3.53 \\
\hline 25 & 3.59 \\
\hline 30 & 3.52 \\
\hline 35 & 3.5 \\
\hline
\end{tabular}

Fineness modulus of natural aggregate, CTA and mixed aggregate of different percentage of tile was found out by sieve analysis. Fineness modulus of natural aggregate was 3.49 and that of $5,10,15,20,25,30,35$ and $100 \%$ tile mixes are $3.55,3.40,3.57,3.52,3.58,3.51,3.49$ and 3.61 respectively. Detail data of grading of aggregates are presented on Appendix-I.

Water Absorption and Specific Gravity:

The specific gravity, water absorption value and water content of different mix are tested on lab. Obtained data are showed in table below. Ceramic tile has higher water absorption value. Due to high water absorption by CTA, W/C ratio will increase proportionally with CTA percentage.

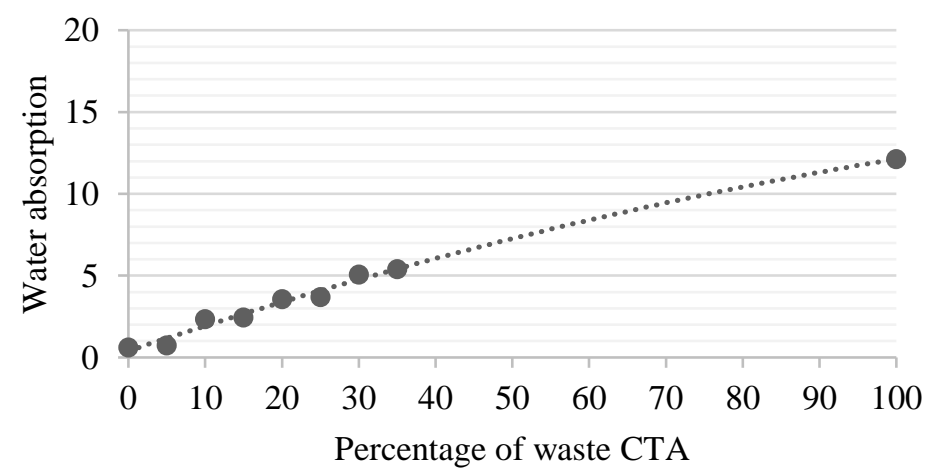

$$
\begin{gathered}
y=-0.0004 x^{2}+0.1572 x+0.4006 \\
R^{2}=0.9924
\end{gathered}
$$

- Water Absorption

Poly. (Water Absorption)

Fig. 4. Water Absorption Value of Aggregate 


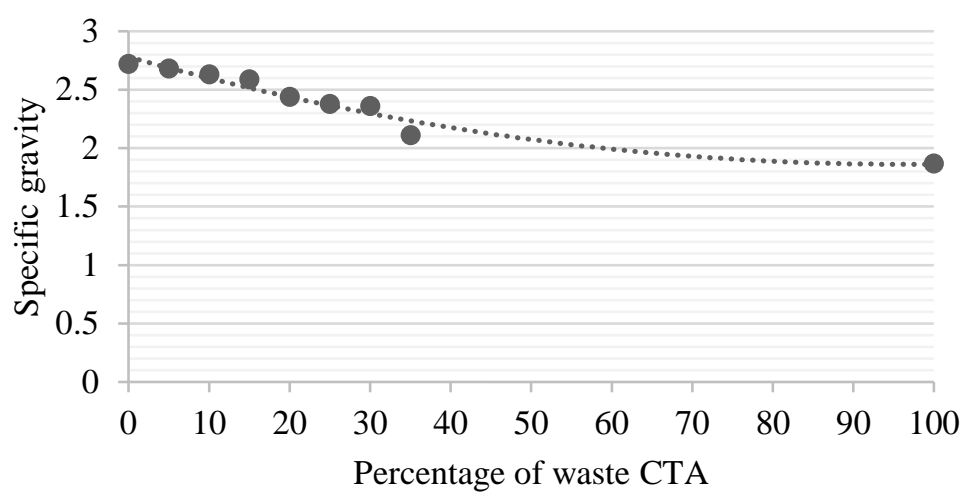

$$
\begin{gathered}
y=1 E-04 x^{2}-0.0191 x+2.78 \\
R^{2}=0.9533
\end{gathered}
$$

- Specific gravity

Poly. (Specific gravity)

Fig. 5. Specific Gravity of Different Mix

TABLE VII. SPECIFIC GRAVITY, WATER ABSORPTION AND

\begin{tabular}{|c|c|c|c|}
\hline \multicolumn{1}{|c}{ mix } & $\begin{array}{c}\text { sp. } \\
\text { gravity }\end{array}$ & $\begin{array}{c}\text { water } \\
\text { absorption }\end{array}$ & $\begin{array}{c}\text { water } \\
\text { content }\end{array}$ \\
\hline $\begin{array}{c}\text { natural } \\
\text { aggregate }\end{array}$ & 2.72 & 0.6 & 0.1 \\
\hline 5\% tile mix & 2.68 & 0.74 & 0.134 \\
\hline $10 \%$ tile mix & 2.63 & 2.34 & 0.175 \\
\hline $15 \%$ tile mix & 2.59 & 2.44 & 0.213 \\
\hline 20\%tile mix & 2.44 & 3.56 & 0.238 \\
\hline 25\%tile mix & 2.38 & 3.68 & 0.288 \\
\hline $30 \%$ tile mix & 2.36 & 5.07 & 0.314 \\
\hline $35 \%$ tile mix & 2.11 & 5.39 & 0.45 \\
\hline ceramic tile & 1.87 & 12.12 & 0.78 \\
\hline
\end{tabular}

\section{Design Mix of Concrete}

The mix design as accordance with Indian standard was done for the concrete mixing for M25 grade. With increase of tile percentage cement quantity also increased. That means cements to aggregate ratio increased. With higher percentage of CTA, water required for mix is also high. That indicates with increase of CTA on concrete, amount of cement and water also increased. The increase in W/C ratio was due to high water absorption value of CTA. W/C ratio was decreased by decreasing the aggregate quantity. I.e. increase in cement to aggregate ratio. W/C ratio of mixes is taken below 0.5 for all types of mixes.
TABLE VIII. MIX PROPORTIONS DESIGNED FOR EXPERIMENT

\begin{tabular}{|c|c|c|c|c|}
\hline Types of mix & Cement & sand & aggregate & w/c \\
\hline $0 \%$ CTA & 1 & 1.55 & 2.71 & 0.479 \\
\hline $5 \%$ CTA & 1 & 1.55 & 2.67 & 0.482 \\
\hline $10 \%$ CTA & 1 & 1.31 & 2.31 & 0.463 \\
\hline $15 \%$ CTA & 1 & 1.31 & 2.28 & 0.464 \\
\hline $20 \%$ CTA & 1 & 1.31 & 2.15 & 0.484 \\
\hline $25 \%$ CTA & 1 & 1.31 & 2.09 & 0.484 \\
\hline $30 \%$ CTA & 1 & 1.31 & 2.07 & 0.492 \\
\hline $35 \%$ CTA & 1 & 1.23 & 2.00 & 0.478 \\
\hline
\end{tabular}

\section{Tests on Hardened Concrete}

Tests performed on concrete during the study are as Cube test:

This test is performed to measure the compressive strength of the concrete. Cubes of $150 \mathrm{~mm}$ size were used for the purpose of test. Cubes were tested for compressive strength at seven and twenty-eight days. With addition of CTA, seven and twenty-eight days compressive strength value also increased. Greater seven days compressive strength was obtained in $10 \%$ CTA mix. $22 \%$ increase on seven days compressive strength was seen on $10 \%$ CTA. $8 \%$ decrease on compressive strength was seen on $35 \%$ CTA mix. 5, 10, 15, 20, 25, 30 percentage mixes have better performance than that of natural aggregate mix. 


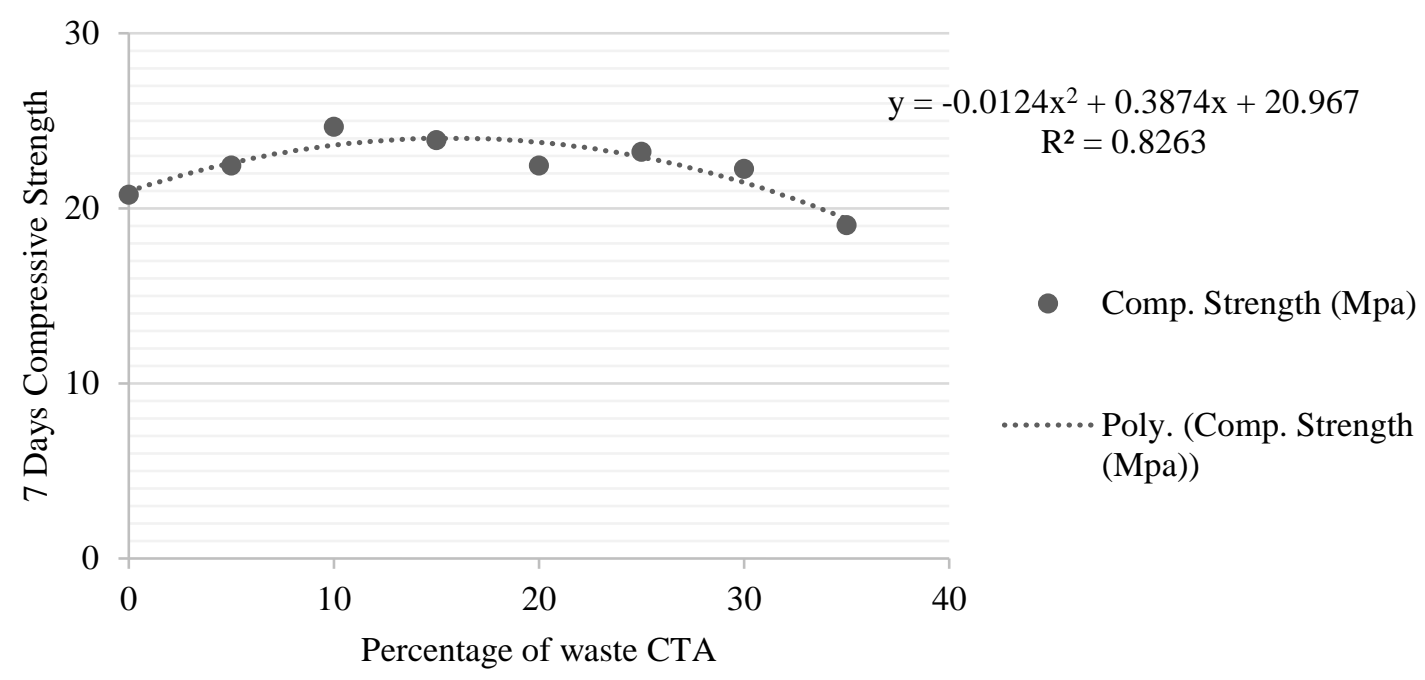

Fig. 6. Seven Days Compressive Strength of Cube

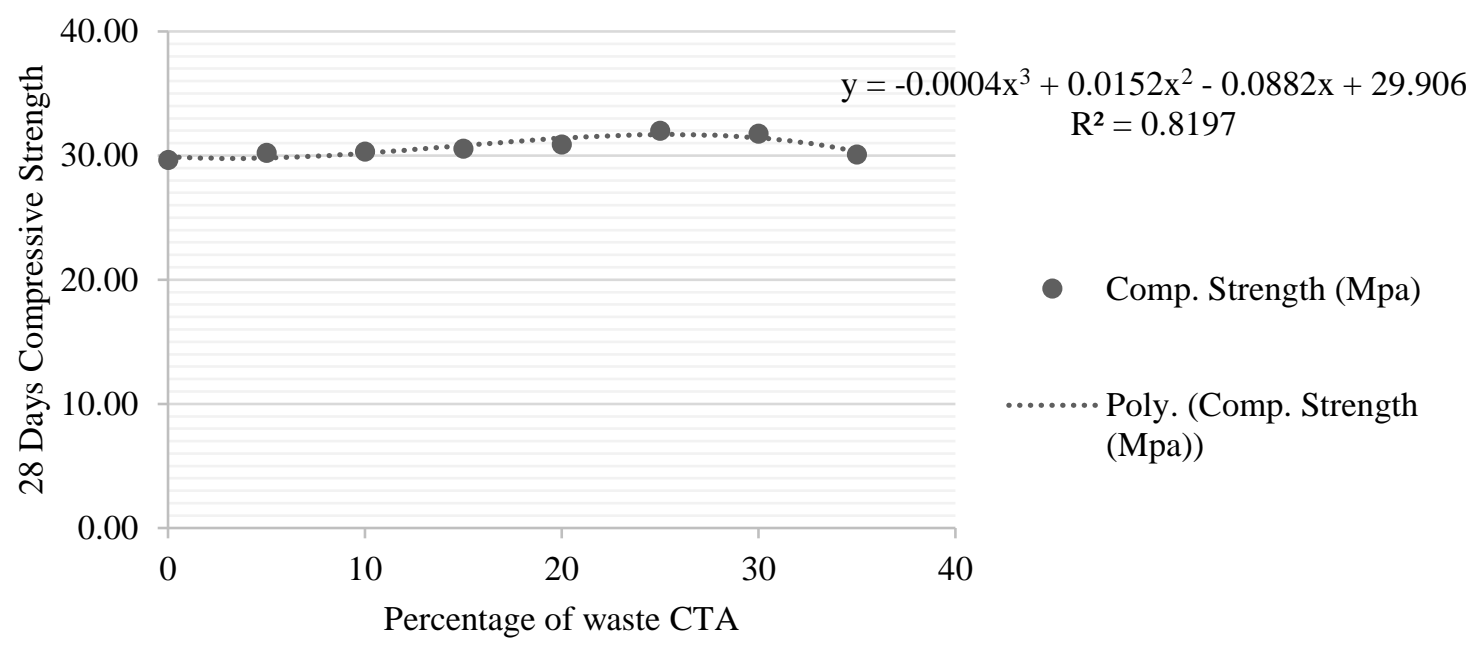

Fig. 7. Twenty-eight Days Compressive Strength of Cube

TABLE IX. SEVEN DAYS DENSITY AND COMPRESSIVE

\begin{tabular}{|c|c|c|}
\hline Mix & Density (gm/cc) & Strength (Mpa) \\
\hline $0 \%$ CTA & 2.43 & 20.78 \\
\hline $5 \%$ CTA & 2.48 & 22.44 \\
\hline $10 \%$ CTA & 2.47 & 24.67 \\
\hline $15 \%$ CTA & 2.43 & 23.89 \\
\hline $20 \%$ CTA & 2.42 & 22.44 \\
\hline $25 \%$ CTA & 2.44 & 23.22 \\
\hline $30 \%$ CTA & 2.39 & 22.26 \\
\hline $35 \%$ CTA & 2.30 & 19.04 \\
\hline
\end{tabular}

Density of Concrete:

This test is performed to measure the density of the concrete. Cubes of $150 \mathrm{~mm}$ size were used for the purpose
TABLE X. TWENTY-EIGHT DAYS DENSITY AND COMPRESSIVE STRENGTH OF CUBE

\begin{tabular}{|c|c|c|}
\hline Mix & Density $(\mathbf{g m} / \mathbf{c c})$ & Strength $(\mathbf{M p a})$ \\
\hline $0 \% \mathrm{CTA}$ & 2.49 & 29.67 \\
\hline $5 \% \mathrm{CTA}$ & 2.50 & 30.22 \\
\hline $10 \% \mathrm{CTA}$ & 2.48 & 30.33 \\
\hline $15 \% \mathrm{CTA}$ & 2.47 & 30.56 \\
\hline $20 \% \mathrm{CTA}$ & 2.48 & 30.89 \\
\hline $25 \% \mathrm{CTA}$ & 2.49 & 32.00 \\
\hline $30 \% \mathrm{CTA}$ & 2.45 & 31.78 \\
\hline $35 \% \mathrm{CTA}$ & 2.32 & 30.11 \\
\hline
\end{tabular}

of test. Densities of cubes were measured at 7 and 28 days. The steps followed while performing tests are as:

Density of concrete $=\frac{\mathrm{W}}{\mathrm{V}}$

Equation 3 


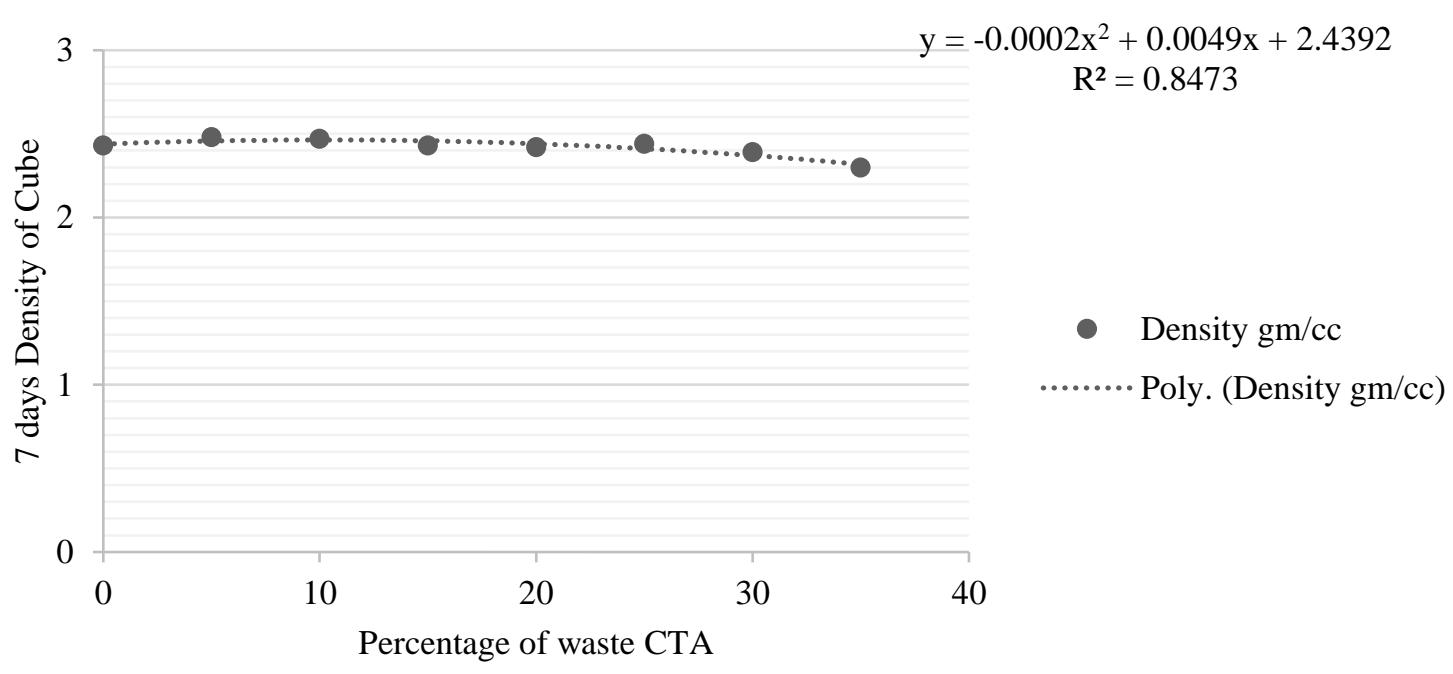

Fig. 8. Density of Hardened Concrete Cube (seven days)

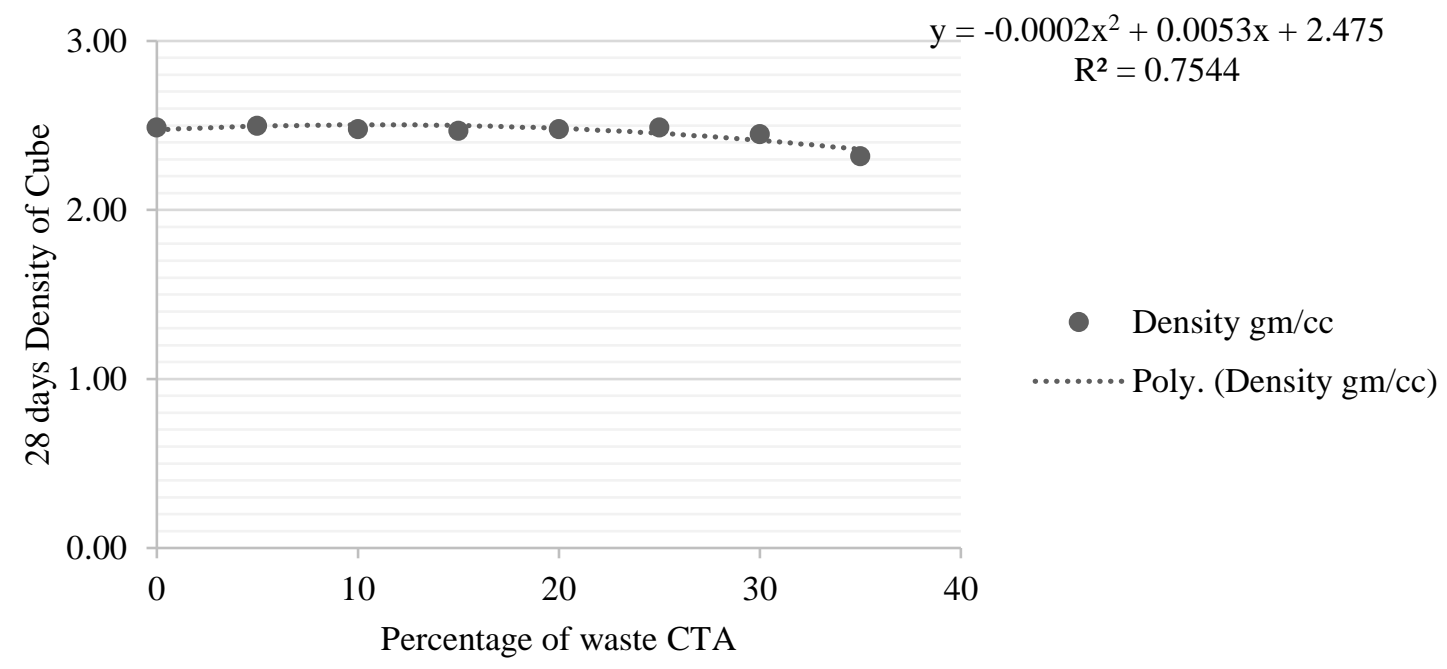

Fig. 9. Density of Hardened Concrete Cube (Twenty-eight days)

The density of hardened concrete also depends on workmanship during concrete casting. Fineness of cement, grading of aggregate, water cement ratio is also governing factor for density of hardened concrete. Concrete with $35 \%$ CTA was obtained $5 \%$ less density than that of $0 \%$ CTA $\operatorname{mix.}$

\section{Rebound Hammer Test:}

At first seven days compressive strength of the cubes were tested by rebound hammer. Smidth hammer only gives the compressive strength of surface whereas CST machine gives strength of whole cube material (from core to surface). At the age of seven days the surface of cube was soft because of less hardening process as well as curing (moist surface). So, the seven days compressive strength obtained on Smidth rebound hammer are lesser than that of CST machine. For 28 days age cube, surface of cube was made dry for rebound hammer test so the strength given by Smidth hammer was nearly as same as strength given by CST machine.
TABLE XI. SMIDTH REBOUND HAMMER TEST DATA OF

\begin{tabular}{|c|c|c|}
\hline Mix & $\begin{array}{c}\text { CUBd days Strength } \\
\text { (Mpa) }\end{array}$ & $\begin{array}{c}\mathbf{2 8} \text { days Strength } \\
\text { (Mpa) }\end{array}$ \\
\hline $0 \%$ CTA & 13.3 & 31.1 \\
\hline $5 \%$ CTA & 14.8 & 31.7 \\
\hline $10 \%$ CTA & 11.3 & 31.9 \\
\hline $15 \%$ CTA & 11.8 & 31.8 \\
\hline $20 \%$ CTA & 10.8 & 32.4 \\
\hline $25 \%$ CTA & 12.2 & 33.6 \\
\hline $30 \%$ CTA & 10.3 & 33.4 \\
\hline $35 \%$ CTA & 10.5 & 31.2 \\
\hline
\end{tabular}

Splitting Tensile Test:

Cylindrical specimen of $10 \mathrm{~cm}$ diameter and $15 \mathrm{~cm}$ height were used for the splitting tensile test. The tests were performed in seven days cured sample. All mixes of concrete cylinder have better splitting tensile values than that of $0 \%$ CTA mix. Thus, we can say that addition of CTA on concrete will increase the seven days split tensile strength of hardened concrete. 20\% CTA mix shows the highest seven days tensile strength. $69 \%$ increase in tensile strength was seen on $20 \%$ CTA mix. 
TABLE XII. DENSITY AND TENSILE STRENGTH OF

\begin{tabular}{|c|c|c|}
\hline Mix & Density (gm/cc) & Strength (Mpa) \\
\hline $0 \%$ CTA & 2.81 & 1.06 \\
\hline $5 \%$ CTA & 2.83 & 1.27 \\
\hline $10 \%$ CTA & 2.78 & 1.27 \\
\hline $15 \%$ CTA & 2.79 & 1.70 \\
\hline $20 \%$ CTA & 2.74 & 1.80 \\
\hline $25 \%$ CTA & 2.69 & 1.59 \\
\hline $30 \%$ CTA & 2.66 & 1.06 \\
\hline $35 \%$ CTA & 2.62 & 1.49 \\
\hline
\end{tabular}

TABLE XIII. DENSITY AND TENSILE STRENGTH OF CYLINDER (TWENTY-EIGHT DAYS)

\begin{tabular}{|c|c|c|}
\hline Mix & Density (gm/cc) & Strength (Mpa) \\
\hline $0 \%$ CTA & 2.82 & 2.65 \\
\hline $5 \%$ CTA & 2.84 & 2.86 \\
\hline $10 \%$ CTA & 2.78 & 2.97 \\
\hline $15 \%$ CTA & 2.82 & 2.97 \\
\hline $20 \%$ CTA & 2.76 & 2.76 \\
\hline $25 \%$ CTA & 2.75 & 3.08 \\
\hline $30 \%$ CTA & 2.69 & 3.29 \\
\hline $35 \%$ CTA & 2.69 & 3.18 \\
\hline
\end{tabular}
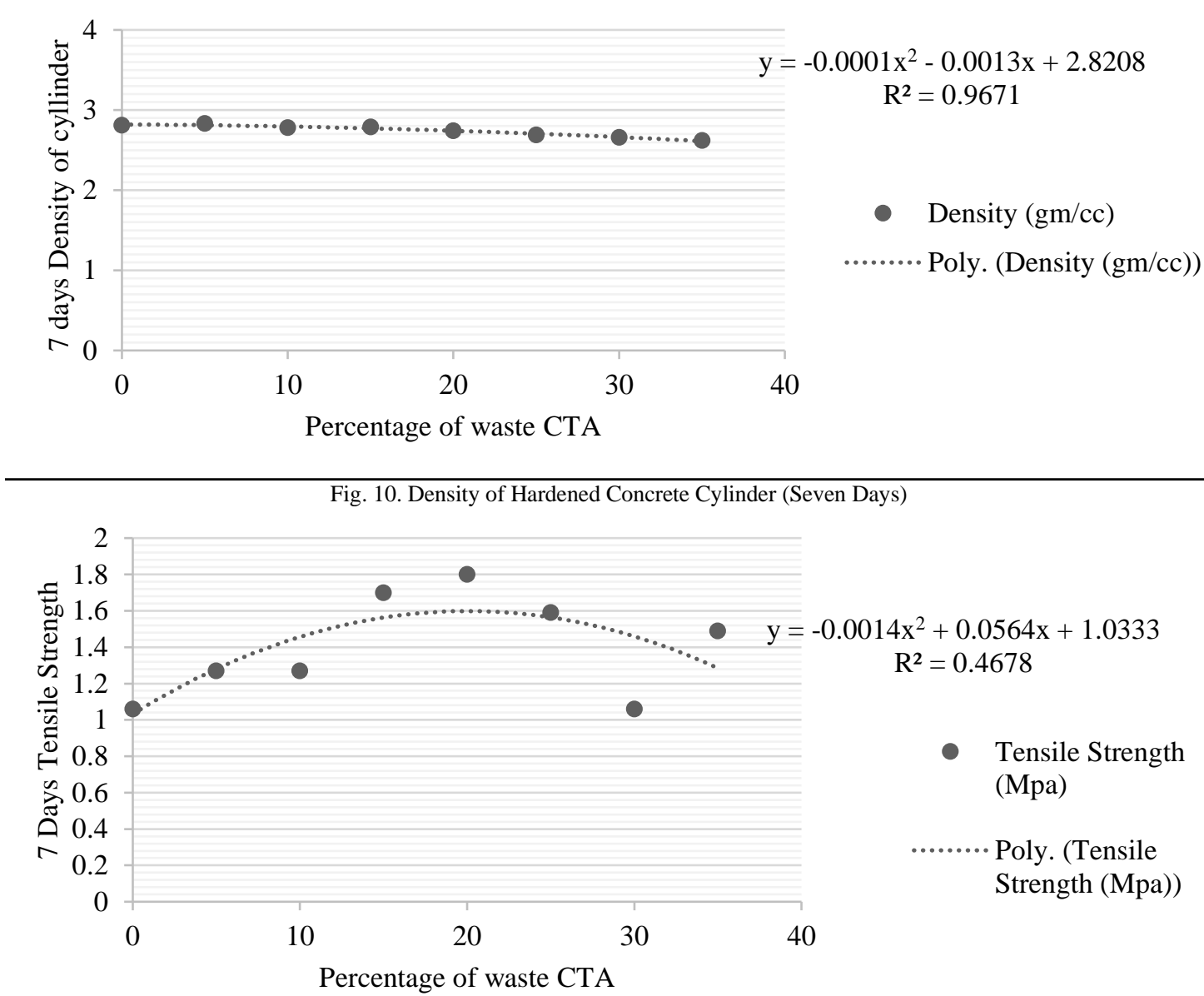

Fig. 11. Tensile Strength of Concrete (Seven Days)

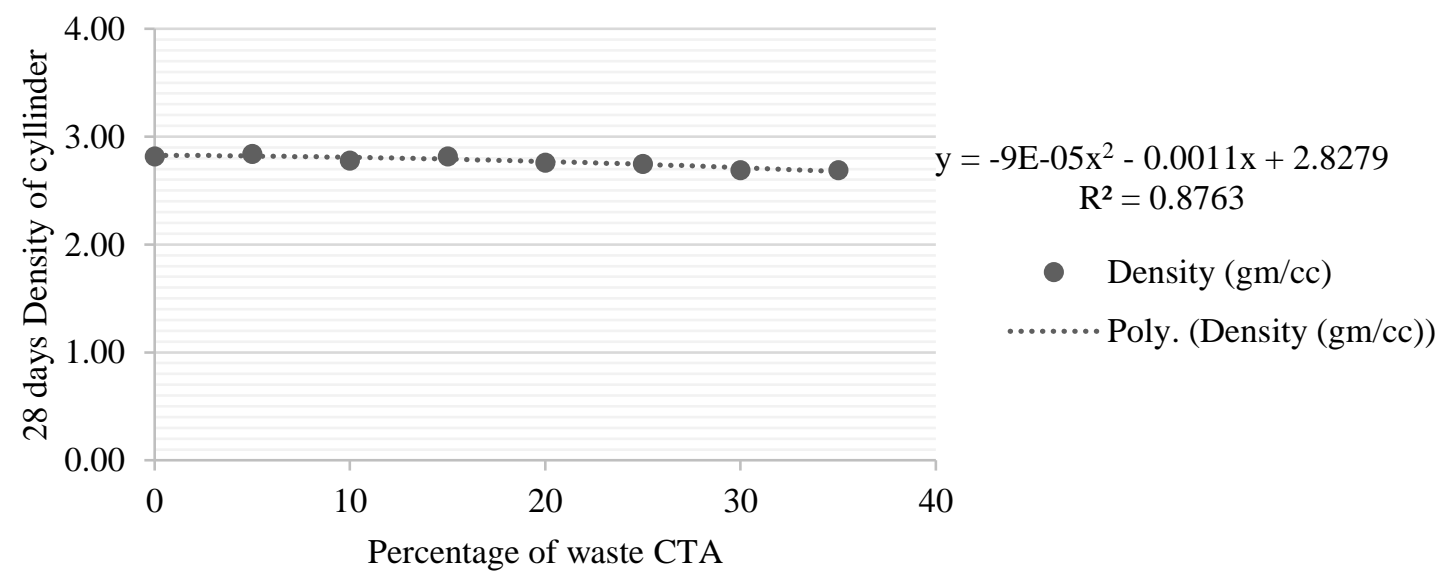

Fig. 12. Density of Cylinder (Twenty-eight days) 


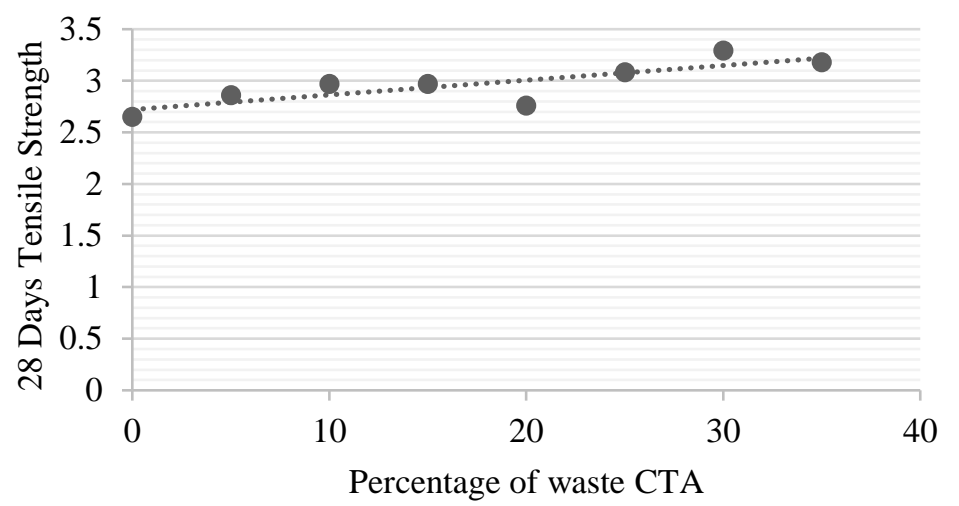

$$
\begin{aligned}
\mathrm{y}= & 0.0142 \mathrm{x}+2.7208 \\
\mathrm{R}^{2} & =0.6711 \\
& \\
& \\
& \text { Tensile Strength } \\
& (\text { Mpa) } \\
\ldots . . . . & \text { Linear (Tensile } \\
& \text { Strength (Mpa)) }
\end{aligned}
$$

Fig. 13. Tensile Strength (Twenty-eight days)

\section{CONCLUSIONS AND RECOMMENDATIONS}

\section{A. Conclusions}

The following conclusions were reached from the present investigations concerning the behavior of crushed tile as coarse aggregate in concrete mixes:

1. Gradation (sieve analysis) of $20 \mathrm{~mm}$ down waste ceramic tile aggregate can be obtained within a permissible value as per IS 383, when tiles are crushed with manual hammering method.

2. $20 \mathrm{~mm}$ down tile crushed aggregate have better flakiness and elongation index than natural crushed aggregate.

3. Ceramic tile aggregate have lower specific gravity, higher water absorption ratio than that of natural aggregate.

4. There is no significantly difference was obtained on impact value of tile and natural aggregate.

5. Up to $30 \%$ replacement of natural aggregate by tile aggregate shows better 7 and 28 days compressive strength than that of $0 \%$ tile aggregate.

6. With addition of tile aggregate, split tensile strength was increased.

\section{B. Recommendation} points

After the present study, we recommend following

1. Waste ceramics tile aggregate can be used in construction industry. For this 15 to 25 percentage replacement of natural aggregate by CTA was preferable.

2. To increase tensile strength of concrete structure 20 to 30 percent replacement of NA by CTA was preferable.

3. As we found that CTA have good physical properties, so, waste ceramics tile should be recycled and reuse.

\section{ACKNOWLEDGEMENT}

Authors are grateful to all faculties, staffs and campus administration of the Pashchimanchal Campus for their valuable advice and support during different stages of the experiments. Authors would like to acknowledge faculties Sailesh Adhikari and Nirmal Prasad Baral; and students
Kishor Chandra Bhandari, Sudip Timalsena and Ram Chandra Poudel of Infrastructure Engineering and Management Program for their support during the study.

\section{REFERENCES}

[1] I. Topcu, "Utilization of crushed tile as aggregate in concrete," Iranian Journal of Science and Technology, 2007.

[2] T. Samreen, H. Shruti and M. P. Gowtam, "Reuse of Ceramic Waste as Aggregate in Concrete," International Research Journal of Engineering and Technology (IRJET), 2016

[3] H. Binici, "Effect of Crushed Ceramic and Basaltic Pumice as Fine Aggregates on Concrete Mortars Properties," Construction and Building Materials, 2007.

[4] CBS, Population Atlas of Nepal, Kathmandu: Central Bureau of Statistics GIS Section, 2014.

[5] H. R. Timalsena, "A Theis Report on Partial Use of Recycled Brick Aggregate in Concrete Production," Pashchimanchal Campus, 2017.

[6] A. Khaloo, "Crushed Tile Coarse Aggregate Concrete," Materials in Civil Engineering, 1995.

[7] A. Choudhury, "Ceramic waste," Roland Institute of Technology 2016.

[8] Y. Tabak, "Ceramic Tile Waste as A Waste Management Solution for Concrete," in International Conference on Industrial and Hazardious Waste Management, 2012.

[9] J. Andres, J. M. Moran, I. M. Guerra, I. M. Sanchez and O. Rodriguez, "Re-Use of Ceramic Wastes in Construction," Wilfried Wunderlich, 2010.

[10] R. Senthamarai and P. D. Manoharan, "Concrete with Ceramic Waste Aggregate," Cement \& Concrete Composites, 2005.

[11] F. Khalif and A. deVenny, "Recycling of demolished masonry rubble as coarse aggregate in concrete," Journal of Materials in Civil Engineering, 2004.

[12] S. Ahmad and M. Daniyal, "Application of Waste Ceramic Tile Aggregates in Concrete," International Journal of Innovative Research in Science, Engineering and Technology , 2015.

[13] IPTS, "Reference Document by Best Available Techniques (BAT) in the Ceramic Manufacturing Industry," Institute for Prospective Technological Studies, Europe, 2007.

[14] IS, "Method of Physical Tests for Hydraulic Cement. Part III," Bureau of Indian Standard, New Delhi, India, 1988.

[15] IS, "Method of Test for Aggregate for Concrete, Part III, Specific Gravity, Density, Voids, Absorption, Bulking," Bureau of Indian Standard, New Delhi, India, 1997.

[16] IS:2386-1963, "Method of Tests for Aggregate for Concrete, Part I, Particle Size and Shape," Bureau of Indian Standard, New Delhi, India, 1997. 
[17] IS:516, "Method of Tests for Strength of Concrete," Bureau of Indian Standard, New Delhi, India, 1959.

[18] IS:4031-1999, "Method of Physical Tests for Hydraulic Cement, Part II, Determination of Fineness of Cement," Bureau of Indian Standard, New Delhi, India, 2004.

[19] IS:4031-1988, "Method of Physical Test for Hydraulic Cement, Part V, Determination of Initial and Final Setting Time of Cement," Bureau of Indian Standard, New Delhi, India, 2005.

[20] IS:4031-1996, "Method of Physical Test for Hydraulic Cement, Part I, Determination of Fineness by Sieving," Bureau of Indian Standard, New Delhi, India, 2005.

[21] IS:383, "Coarse and fine Aggregate for Concrete (Third Revision), Bureau of Indian Standard, New Delhi, India, 2016. 